\title{
$\underline{\mathbf{P}-83}$
}

\section{Isolation and Characterization of Chemical Constituents from the Flower of Calliandra Surinamensis Benth}

\author{
Siti Muhayyah Omar*, Norizan Ahmat, Nik Fatini Nik Azmin, Carla Wulandari Sabandar and Laode \\ Muhammad Ramadhan Al Muqarrabun
}

Faculty of Applied Sciences, Universiti Teknologi MARA (UiTM), 40450, Shah Alam, Selangor Darul Ehsan, Malaysia; E-mail: noriz118@salam.uitm.edu.my

Calliandra is a genus of flowering plant that is widely distributed in the tropical and subtropical regions of southern Asia, Africa, Australia and America. Calliandra surinamensis is a large multiple trunked, low branching evergreen shrub that has silky leaflets, which are glossy copper when new, turning to a dark metallic green. The flower is pink colored with pleasant fragrant. Calliandra surinamensis or its local name Pink Powderpuff (Kaliandra bunga merah) is belongs to the family of Leguminosae and subfamily of Mimosoideae. The flower pigment of Calliandra surinamensis is used folklorically as a colorant and dye. Besides, in folk medicine, the stem bark of this plant was reported to be able to treat various diseases and infections such as cough, wound healing, inflammation and antimicrobial activities [1]. The antioxidant or free radical scavenging activities of the stem bark using standard experimental procedures has been reported [2]. The flower of Calliandra surinamensis were extracted by successive extraction. About 70 grams of the Calliandra surinamensis flower was defatted in methanol $\left(40^{\circ} \mathrm{C}-60^{\circ} \mathrm{C}\right)$ for 48 hours and repeated for three times to yield 40 grams of methanol extract. The phytochemical screening on the crude extract was tested for flavonoid and alkaloids. The phytochemical procedures adopted were vacuum liquid chromatography (VLC), column chromatography, radial chromatography and preparative thin layer chromatography. Phytochemical investigation of Calliandra surinamensis flower has afforded three compounds which are 3-orhamnosylquercitrin (1), 5'-prenylated kaempferol (2) and quercetin (3). The structural elucidation of isolated compounds were accomplished by spectroscopic method such as $1 \mathrm{D}-\mathrm{NMR}\left({ }^{1} \mathrm{H},{ }^{13} \mathrm{C}, \mathrm{DEPT}\right)$ and 2D-NMR (COSY, HMQC, HMBC), UV, IR, MS and comparison with published data.

Keywords: Leguminosae, Calliandra surinamensis, spectroscopic method, 3-O-rhamnosylquercitrin, 5'-prenylated kaempferol and quercetin.

\section{REFERENCES}

[1] Falodun A, Irabor EI. Acta Poloniae Pharm Drug Res 2008; 65: 571-5.

[2] Emmanuel EI, Falodun A, Obasuyi O, Ofoegbu CO, Abiodun SO, Kingsley U. Acta Poloniae Pharm Drug Res 2007; 63: 449-51. 